\title{
Upregulation of Kruppel-like Factor 4 Gene expression by Allomyrina dichotoma Hemolymph in the INS-1 Pancreatic $\beta$-cells
}

\author{
Kisang Kwon ${ }^{1, *}$, Hyun-Woo Suh ${ }^{1, *}$, Hong Geun Kim ${ }^{2, *}$ and O-Yu Kwon ${ }^{1, ;, * *}$ \\ ${ }^{1}$ Department of Anatomy \& Cell Biology, College of Medicine, Chungnam National University, \\ Daejeon 35015, Korea \\ ${ }^{2}$ Research Center for Endangered Species, National Institute of Ecology, Yeongyang 36531, Korea
}

\begin{abstract}
The hemolymph of Korean rhinoceros Allomyrina dichotoma consists of blood and lymph in which various kinds of proteins function physiologically. We have previously demonstrated that A. dichotoma hemolymph has the potential to treatment and prevent diabetes through activating transcription factor 3-gene (ATF3) regulation. In this study, we investigate the expression of Kruppel-like factor 4 (KLF4) in A. dichotoma hemolymph-treated INS-1 pancreatic $\beta$-cells. The new findings show that $A$. dichotoma hemolymph, which upregulates KLF4 gene expression in a dose-dependent and timedependent manner. In addition, hemolymph combine with mild endoplasmic reticulum (ER) stress, which also differentially regulates KLF4 gene expression. These results may provide insights to KLF4 gene-related disease therapies through KLF4 gene regulation.
\end{abstract}

Key Words: Allomyrina dichotoma, Hemolymph, Kruppel-like factor 4 (KLF4)

Recently, Food and Agriculture Organization of the United Nations (FAO) reported that edible insects such as grasshoppers (Sphenarium purpurascens), crickets (Gryllus bimaculatus), mealworms (Tenebrio molitor), and buffalo worms (Alphitobius diaperinus), should be recognized as one of the great potential future food sources in which high quality protein, vitamins and amino acids can be obtained (Nowak et al., 2016; Tao and Li, 2018; van Huis, 2013). Korean rhinoceros beetles (Allomyrina dichotoma) are regarded as a traditionally medicine for liver-related diseases in Korea (Choi et al., 2006; Kim et al., 2007). It was reported that $A$. dichotoma boiled-extract demonstrates effectiveness as anti-hepatofibrotic, anti-neoplastic, antibiotic, anti-diabetic and anti-obesity at the experimental level (Miyanoshita et al., 1996; Yoshikawa et al., 1999; Sagisaka et al., 2001; Chung et al., 2014; Kim et al., 2015; Kim et al., 2016). In addition, our previous study has shown that hemolymph of A. dichotoma activates transcription factor 3 (ATF3) gene, which indicates a potential for the possible treatment of diabetes (Kim et al., 2018). Hemolymph of insect is the circulating fluid functionally analogous to the blood and lymph of vertebrates, and consists of some kinds of hemocytes and various ions, carbohydrates, lipids, proteins and hormones (Blow and Douglas, 2019; Pendar et al., 2019). Up to date, in all experiments of insect bioactivity, two types of insect sample were used either crushed dried-insects into a powder or boiled extract of insect. However, in this study, we used raw insect hemolymph directly for the functional

Received: March 11, 2020 / Revised: March 24, 2020 / Accepted: March 26, 2020

${ }^{*}$ Researcher, ${ }^{* *}$ Professor.

$\dagger$ Corresponding author: O-Yu Kwon. Department of Anatomy \& Cell Biology, College of Medicine, Chungnam National University, Daejeon 35015, Korea. Tel: +82-42-580-8206, Fax:+82-42-586-4800, e-mail: oykwon@cnu.ac.kr

(C) The Korean Society for Biomedical Laboratory Sciences. All rights reserved.

(C) This is an Open Access article distributed under the terms of the Creative Commons Attribution Non-Commercial License (http://creativecommons.org/licenses/by-nc/3.0/) which permits unrestricted non-commercial use, distribution, and reproduction in any medium, provided the original work is properly cited. 
study for purposes of maintaining the protein activity. Kruppel-like factor 4 (KLF4) is known as a transcription factor which has zinc finger DNA-binding capacity that regulates gene expression associated with proliferation, antiinflammation, and apoptosis of the cells (Tang et al., 2019). Some of the disorders that have reportedly resulted from KLF4 gene-related diseases include secretory meningioma, cerebral cavernous malformations, skin squamous cell carcinoma, germ cell, embryonal cancer, and familial adenomatous polyposis (Morales-Martinez et al., 2019).

Herein, we demonstrate the upregulation of KLF4 gene in A. dichotoma hemolymph-treated INS-1 pancreatic $\beta$-cells. The gene expression of KLF4 is significantly up regulated in transcriptional level from our previous cDNA microarray experiment (Kim et al., 2018). Hemolymph exposure in INS- 1 cells for $2 \mathrm{~h}$ resulted in 7.06-folds increase in KLF4 levels as compared to the control genes. As such, KLF4 was used as the target gene for the current experiment.

Hemolymph used in this experiment was extracted from a healthy third-instar larva of $A$. dichotoma. The collected hemolymph was incubated for $5 \mathrm{~min}$ using $5 \mathrm{~mL}$ of thrombin to $500 \mathrm{~mL}$ of hemolymph at room temperature. In order to remove the insoluble matters including several kind of blood cells, the hemolymph was centrifuged for $5 \mathrm{~min}$ at $11,000 \mathrm{x} \mathrm{g}$ at temperatures of $4^{\circ} \mathrm{C}$. After dialysis and subsequent filtering through $0.22 \mathrm{~mm}$ syringe filter, the supernatant was divided and stored at $-70^{\circ} \mathrm{C}$ until following experiment. The concentration of the final protein was 2.5 $\mathrm{mg} / \mathrm{mL}$ as measured by Bio-Rad protein assay kit. INS-1 pancreatic $\beta$-cells were cultured in RPMI-1640, and supplemented with $10 \%$ fetal calf serum (Gibco BRL, Gaithersburg, MD), $100 \mathrm{U} / \mathrm{mL}$ penicillin, $100 \mu \mathrm{g} / \mathrm{mL}$ streptomycin, $2 \mathrm{mM} /$ $\mathrm{mL}$ L-glutamine, $10 \mathrm{mM} / \mathrm{mL}$ HEPES, $1 \mathrm{mM} / \mathrm{mL}$ sodium pyruvate, and $50 \mathrm{mM} / \mathrm{mL}$ 2-mercaptoethanol, in a humidified environment $\left(5 \% \mathrm{CO}_{2}, 37^{\circ} \mathrm{C}\right)$. Analysis to identify genes that are differentially expressed was conducted using Agilent's Gene Expression Hybridization. Scan and image analysis conducted using Agilent's DNA microarray scanner and DNA analysis was by Agilent's GeneSpring Software Kit (Agilent, Santa Clara, CA, USA). Total RNA was extracted using the SV Total RNA Isolation system (Promega, Madison, WI, USA). The mRNA in the samples was reverse-transcribed using a SuperscriptII ${ }^{\mathrm{TM}}$ First Strand Kit (Invitrogen Carlsbad, CA, USA). The resulting cDNA was amplified by PCR using the primer pair's mouse actin $F$ (5'-GAAATCCACCAAAGCTCAC-3') and R (5'-TCTCGGTCAAGTTCAACATC-
A

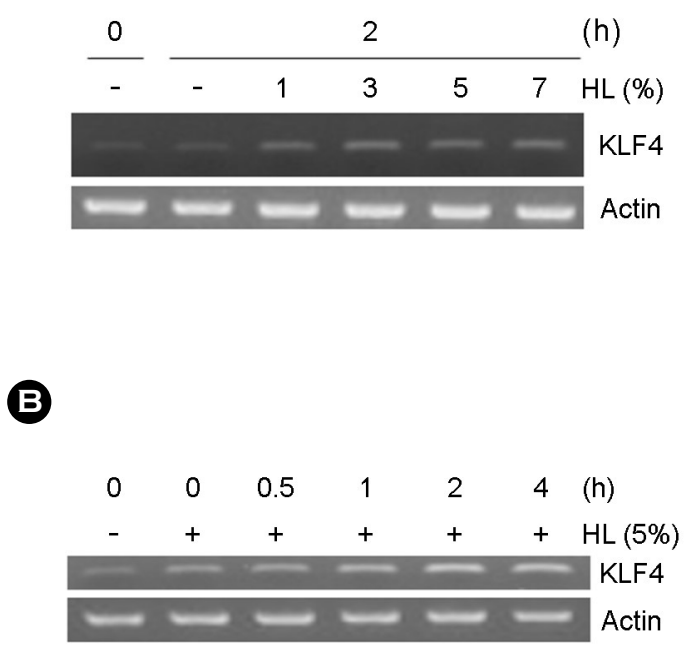

C

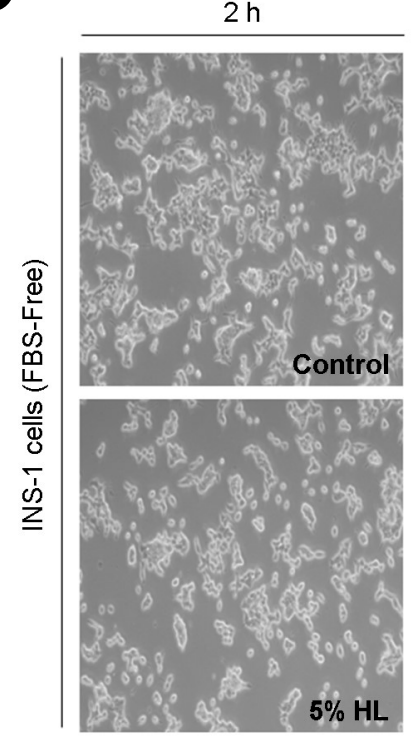

$4 \mathrm{~h}$

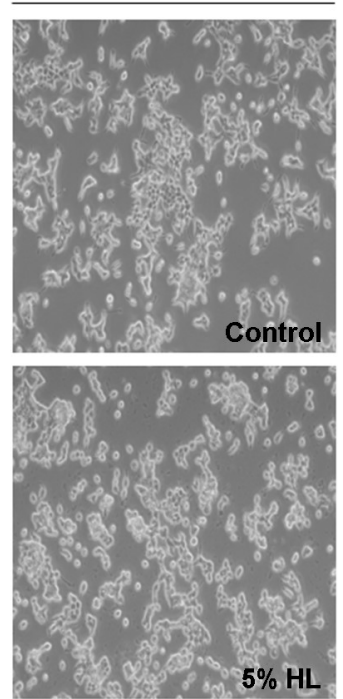

Fig. 1. A. dichotoma hemolymph enhances KLF4 gene expression in the INS-1 pancreatic $\beta$-cells. (A) Dose-dependent effect of $A$. dichotoma hemolymph for KLF4 gene expression. (B) Time-dependent effect of A. dichotoma hemolymph for KLF4 gene expression. (C) Photomicrograph of INS-1 pancreatic $\beta$-cells morphology because of A. dichotoma hemolymph treatment. 
(A)

\begin{tabular}{|c|c|c|c|c|c|c|}
\hline \multicolumn{6}{|c|}{$32^{\circ} \mathrm{C}$} & \multirow{3}{*}{$\begin{array}{l}(H) \\
H L(5 \%)\end{array}$} \\
\hline \multicolumn{2}{|c|}{1} & \multicolumn{2}{|c|}{2} & \multicolumn{2}{|c|}{4} & \\
\hline - & + & - & + & - & + & \\
\hline 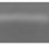 & $=$ & $=$ & $=$ & 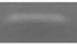 & $=$ & KLF4 \\
\hline$=$ & $=$ & 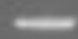 & 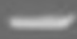 & 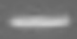 & 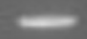 & Actin \\
\hline
\end{tabular}

B

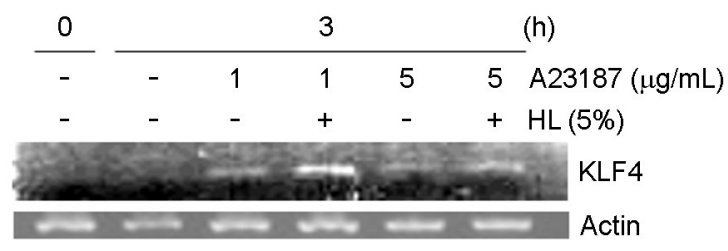

Fig. 2. (A) Low temperature regulates KLF4 gene expression. (B) ER stress inducible drug (A23187) regulates KLF4 gene expression.

3') and KLF4 F (5'-CTGAACAGCTCAGGGACTGTCA -3') and KLF4 R (5'-GTGTGGGTGGCTGTTCTTT-3'). RTPCR conditions for 30 cycles were $94^{\circ} \mathrm{C}$ for $30 \mathrm{~s} ; 58^{\circ} \mathrm{C}$ for $30 \mathrm{~s}$; and $72^{\circ} \mathrm{C}$ for $1 \mathrm{~min}(10 \mathrm{~min}$ in the final cycle), using both primers mentioned above with Taq DNA polymerase.

In this study, we investigate the effect of A. dichotoma hemolymph on the gene expression of KLF4 in the INS-1 pancreatic $\beta$-cells. As shown in Fig. 1A, KLF4 gene expression is upregulated dose-dependently on the A. dichotoma hemolymph after $2 \mathrm{~h}$ exposure. After the addition of $1 \%$ hemolymph, KLF4 gene expression was higher than its con trol. Fig. 1B presents the result of time-dependent expression of KLF4 gene under $5 \%$ A. dichotoma hemolymph. Gene expression of KLF4 is upregulated to $0.5 \mathrm{~h}$ exposure. It was confirmed that KLF4 gene expression was upregulated in both instances of dose-dependent and time-dependent aspects of hemolymph experiments. In addition, as a result of microscopic observation of the cells, the morphology of the cells is almost unchanged because the hemolymph is not cytotoxicity (Fig. 1C).

INS-1 pancreatic $\beta$-cells were incubated at $32^{\circ} \mathrm{C}$ for 1,2 , and $4 \mathrm{~h}$ in $5 \%$ A. dichotoma hemolymph, in order to understand the possibility of hypothermia treatment through the regulation of KLF4 gene expression (Kim et al., 2018). As shown in Fig. 2A, there were no significant changes observed in KLF4 gene expression due to hypothermia treatment. ER comprises an advanced signal transducing system that functions in perpetuating cellular homeostasis through posttranslational modification of secretory proteins (Baiceanu et al., 2016). Stresses in the ER are induced by unfolded protein response (UPR) to adaption and survival of cells and/or tissues by expression of ER chaperones such as binding immunoglobulin protein (BiP), calreticulin and protein ERp29
(Kwon et al., 2000; McCaffrey and Braakman, 2016). Next, testing of regulation of KLF4 gene expression by ER stress was observed using ER stress inducible drug (A23187). It was observed that KLF4 gene expression is upregulated by relatively weak $(1 \mathrm{mg} / \mathrm{mL})$ instead of strong $(5 \mathrm{mg} / \mathrm{mL})$ ER stress induction (Fig. 2B).

Many recent results provide evidences that effects of edible insect extracts against liver diseases (Ahn et al., 2014; Im et al., 2017; Kim and Chae, 2018; Lee et al., 2017a; Lee et al., 2017b). Our results also provide an insight to the development of KLF4-related disease therapies through gene expression regulation of KLF4 using A. dichotoma hemolymph combined with mild ER stress (Yoshida \& Hayashi, 2014; Lu et al., 2015).

\section{ACKNOWLEDGEMENT}

This work was supported by the National Research Foundation of Korea (NRF) grant funded by the Korea government (MSIT) (No. NRF-2017R1D1A3B03033200).

\section{CONFLICT OF INTEREST}

The authors declare that no conflict of interest.

\section{REFERENCES}

Ahn MY, Han JW, Hwang JS, Yun EY, Lee BM. Antiinflammatory effect of glycosaminoglycan derived from Gryllus bimaculatus on adjuvant-treated chronic arthritis rat model. J Toxicol Environ Health Part A. 2014. 7: 1332-1345.

Baiceanu A, Mesdom P, Lagouge M, Foufelle F. Endoplasmic reticulum proteostasis in hepatic steatosis. Nat Rev Endocrinol. 2016. 124: 710-722.

Blow F, Douglas AE. The hemolymph microbiome of insects. J 
Insect Physiol. 2019. 115: 33-39.

Choi YH, Lee KY, Yang KM, Jeong YM, Seo JS. Effect of larva extract of Allomyrina dichotoma on carbon tetrachlorideinduced hepatotoxicity in mice. Prev Nutr Food Sci. 2006. 35: 1349-1355.

Chung MY, Yoon YI, Hwang JS, Goo TW, Yun EY. Anti-obesity effect of Allomyrina dichotoma (Arthropoda: Insecta) larvae ethanol extract on 3T3-L1 adipocyte differentiation. Entomol Res. 2014. 44: 9-16.

Im AR, Yang WK, Park YC, Kim TH, Ahn HY, Kim YW, Sim SY, Seo KI, Cho YS. Biological activity and biochemical properties of water extracts from Bacillus subtilis-fermented silkworm (Bombyx mori L.) powder by origin. J Life Sci. 2017. 27: $1470-1478$.

Kim DS, Huh J, You GC, Chae SC, Lee OS, Lee HB, Lee JB, Kim JS. Allomyrina dichotoma larva extracts protect streptozotocininduced oxidative cytotoxicity. Environ Health Toxicol. 2007. 22: 349-355.

Kim HG, Kwon K, Suh HW, Lee S, Park KH, Kwon OY, Choi JY. Exosome isolation from hemolymph of Korean rhinoceros beetle, Allomyrina dichotoma (Coleoptera: Scarabaeidae). Entomol Res. 2015. 45: 339-344.

Kim J, Yun EY, Park SW, Goo TW, Seo M. Allomyrina dichotoma larvae regulate food intake and body weight in high fat dietinduced obese mice through mTOR and Mapk signaling pathways. Nutrients. 2016. 8: 100.

Kim SH, Chae S. Hepatoprotective effects of insect extracts in an animal model of nonalcoholic fatty liver disease. Nutrients. 2018. 10: pii: E735.

Kim SW, Suh HW, Yoo BK, Kwon K, Yu K, Choi JY, Kwon OY. Larval hemolymph of rhinoceros beetle, Allomyrina dichotoma, enhances insulin secretion through ATF3 gene expression in INS-1 pancreatic $\beta$-cells. Z Naturforsch. C 2018. 73: 391-396.

Kwon OY, Park S, Lee W, You KH, Kim H, Shong M. TSH regulates a gene expression encoding ERp29, an endoplasmic reticulum stress protein, in the thyrocytes of FRTL-5 cells. FEBS Lett. 2000. 475: 27-30.

Lee J, Hwang IH, Kim JH, Kim MA, Hwang JS, Kim YH, Na M. Quinoxaline-, dopamine-, and amino acid-derived metabolites from the edible insect Protaetia brevitarsis seulensis. Arch Pharm Res. 2017a. 40: 1064-1070.

Lee J, Lee W, Kim MA, Hwang JS, Na M, Bae JS. Inhibition of platelet aggregation and thrombosis by indole alkaloids isolated from the edible insect Protaetia brevitarsis seulensis (Kolbe).
J Cell Mol Med. 2017b. 21: 1217-1227.

$\mathrm{Lu}$ XJ, Shi Y, Chen JL, Ma S. Krüppel-like factors in hepatocellular carcinoma. Tumour Biol. 2015. 36: 533-541.

McCaffrey K, Braakman I. Protein quality control at the endoplasmic reticulum. Essays Biochm. 2016: 60: 227-235.

Miyanoshita A, Hara S, Sugiyama M, Asaoka A, Taniai K, Yukuhiro $\mathrm{F}$, Yamakawa M. Isolation and characterization of a new member of the insect defensing family from a beetle, Allomyrina dichotoma. Biosci Biotechnol Res Commun. 1996. 220: 526 -531 .

Morales-Martinez M, Valencia-Hipolito A, Vega GG, Neri N, Nambo MJ, Alvarado I, Cuadra I, Duran-Padilla MA, Martinez-Maza O, Huerta-Yepez S, Vega MI. Regulation of Krüppel-Like Factor 4 (KLF4) expression through the transcription factor Yin-Yang 1 (YY1) in non-Hodgkin B-cell lymphoma. Oncotarget. 2019. 10: 2173.

Nowak V, Persijn D, Rittenschober D, Charrondiere UR. Review of food composition data for edible insects. Food Chem. 2016. 193: 39-46.

Pendar H, Aviles J, Adjerid K, Schoenewald C, Socha JJ. Functional ompartmentalization in the hemocoel of insects. Sci Rep. 2019. 9: 6075.

Sagisaka A, Miyanoshita A, Ishibashi J, Yamakawa M. Purification, characterization and gene expression of a glycine and prolinerich antibacterial protein family from larvae of a beetle, Allomyrina dichotoma. Insect Mol Biol. 2001. 10: 293-302.

Tang RZ, Zhu JJ, Yang FF, Zhang YP, Xie SA, Liu YF, Yao WJ, Pang W, Han LL, Kong W, Wang YX. DNA methyltransferase 1 and Krüppel-like factor 4 axis regulates macrophage inflammation and atherosclerosis. J Mol Cell Cardiol. 2019. 128: 11-24.

Tao J, Li YO. Edible insects as a means to address global malnutrition and food insecurity issues. Food Qual Saf. 2018. 2: 17-26.

van Huis A. Potential of insects as food and feed in assuring food security. Annu Rev Entomol. 2013. 58: 563-583.

Yoshida T, Hayashi M. Role of Krüppel-like factor 4 and its binding proteins in vascular disease. J Atheroscler Thromb. 2014. 21: 402-413.

Yoshikawa K, Umetsu K, Shinzawa H, Yuasa I, Maruyama K, Ohkura T, Yamashita K, Suzuki T. Determination of carbohydrate deficient transferring separated by lectin affinity chromatography for detecting chronic abuse. FEBS Lett. 1999. 458: 112-116. 
https://doi.org/10.15616/BSL.2020.26.1.37

Cite this article as: Kwon K, Suh HW, Kim HG, Kwon OY. Upregulation of Kruppel-like Factor 4 Gene expression by Allomyrina dichotoma Hemolymph in the INS-1 Pancreatic $\beta$-cells. Biomedical Science Letters. 2020. 26: 37-41. 